appointment that the numerous inquiries and conferences held during the past year have not yet had any result. Local investigation with regard to the movements of herring shoals is insufficient. In this case the shoals leave Northumbrian waters and appear later on off the Firth of Forth, where, apparently, they are not sampled or investigated. It is therefore regrettable, Prof. Meek suggests, that reconstruction should have been a departmental rather than a national affair.

\section{J. J.}

\section{Flora of the Hawaian Islands.}

THE natural history of the Hawaian Islands has been well worked as regards both the flora and the fauna. Generally speaking, there is an extraordinary degree of endemism in the plants and animals, associated with a strong Southern Pacific or Australasian and Indo-Malayan affinity and a weak Northern Pacific or American affinity. The islands are extremely isolated, being further removed from any continental area than is any other region of equal size upon the globe. The nearest continent is North America, two thousand miles away, and the nearest islands of any importance, the Marquesas, are I860 miles distant. Within forty miles of the shores the ocean exceeds $10,000 \mathrm{ft}$. in depth, and between the islands and the American coast reaches in places more than $20,000 \mathrm{ft}$. The most commonly accepted view of the origin of the archipelago is that the islands, which are entirely volcanic, were raised by volcanic activity, and that they have always been completely isolated.

In a paper entitled "The Derivation of the Flora of Hawaii" (Leland Stanford Junior University Publications, University Series, I9I9) Prof. D. H. Campbell gives a résumé of the composition of the flora and its relations to American and Southern Pacific foras generally, and criticises unfavourably Guppy's view of its origin and distribution. Guppy accepts the view that the archipelago has always been completely isolated, and that air-currents and birds have been the agents concerned in its population. The predominantly Australasian and Indo-Malayan element was, he suggests, introduced largely by birds, especially fruit-eating pigeons, but Prof. Campbell finds a serious objection in the absence of such birds from the present fauna, as, apart from a number of American migratory shore-birds, practically all are endemic. Prof. Campbell strongly supports the view taken by Mr. H. A. Pilsbry, based on the study of the molluscan fauna. The land-snails are all ancient types the modern representatives of which are largely confined to Polynesia, and they represent, it is contended, an ancient fauna which has survived from a time when Hawaii was part of a continental area connected to the south-west with that of Polynesia. A study of the insects leads to a similar general conclusion, namely, that while the ancestors of some of the species mav have been introduced through the agency of wind- or ocean-currents or by migratory birds, there are many more species of both plants and animals the presence of which can best be explained by a former more or less direct land-connection between Hawaii and the Indo-Malavan region.

The multitude of islands constituting Polvnesia are. on this hypothesis, the remains of a once extensive land-mass, either a single continent or several large continental islands like Australia. This great area has been subsiding since Early Tertiary times, and the existing islands are the tnos of mountain masses. often volcanic, superimnosed upon this submerged continental area. A serious objection to this theory is the absence in Hawail of certain types of vegetation characteristic of Southern Pacific regions, such as the conifers, aroids, and figs, and it is suggested that these forms became extinct after the isolation of the islands. Similar examples of such disappearance of plants are afforded by Sequoia, Liriodendron, and other genera, which had once a wide distribution, but are now represented in many regions only by Tertiary fossils.

\section{University and Educational Intelligence.}

Dr. J. B. Cleland, of the Health Department of New South Wales, has been appointed to fill the newly constituted chair of pathology in the University of Adelaide, South Australia.

Applicatrons for grants from the Dixon Fund, of the University of London, for assisting scientific investigations, are receivable by the Academic Registrar, University of London, South Kensington, S.W.7, until May 14 next. They must be accompanied by the names and addresses of two referees.

The Marguess of Crewe, chairman of the governing body of the Imperial College of Science and Technology, and Sir Alfred Keogh, Rector of the college, will attend the annual dinner of the Old Students Association of the Royal College of Science, to be held at the Café Monico on Saturday, April 24. Other distinguished guests will be Prof. W. H. Bragg, Dr. W. Garnett, Sir Richard Glazebrook, Mr. W. McDermott, and Sir Ronald Ross. Tickets (price Ios. 6d.) may be obtained from Mr. C. S. Garland, acting secretary, Old Students Association, Royal College of Science, South Kensington, London, S.W.7.

Aт a general meeting of old students held recently at King's College, Strand, it was decided to form a King's College, London, Old Students' Association for the purpose of promoting social intercourse and of keeping the members in touch with their old college. The association hopes to include students from all faculties, and the subscription of ros. $6 d$. per annum will include the King's College Review, published once a term, and a list of members with their addresses (and possibly the work on which they are engaged). Further particulars and forms of application for membership may be obtained from Miss M. A. V. Fairlie, hon. secretary, 3 St. Julian's Farm Road, West Norwood, S.E.27.

\section{Societies and Academies.}

Faraday Society, March 1.-Dr. T. Martin Lowry and F. C. Hemmings: The properties of powders. The caking of salts is, in general, dependent on the presence of a solvent, usually water. The following cases have been studied: Nitrates, other anhydrous compounds, hydrated salts, loss of sulphur dioxide during caking and contraction during caking of copper sulphate.-Dr. T. Martin Lowry and S. Wilding: The setting of dental cements. Phenomena of caking or setting may be divided into five classes:-(r) Recrystallisation of anhydrous or hydrated salt without change of chemical composition. (2) Formation of hydrates. (3) The hydrolysis of complex salts by water. (4) The formation of new salts, such as the magnesium oxy-cements and the zinc oxy-phosphate cements used in dentistry, and "silicate" cements. (5) Amalgams in which mercury takes the place of water.

Zoolegical Society, March 16.-Prof. E. W. MacBride, vice-president, in the chair.-R. I. Pocock : NO. 2633 , VOL. I05] 
External characters of the South American monkeys. The paper showed the variations in the range of structure of the ears, nose, hands, feet, and external genitalia.-Dr. C. F. Sonntag: The comparative anatomy of the tongues of the mammalia. Having first outlined the plan which would be followed in his series of comparative studies, the author proceeded to describe the different divisions of the tongue and the physical characters of each. He demonstrated by diagrams and lantern-slides the different forms which the papillæ and openings of Wharton's ducts can assume among the mammalia, and exhibited specimens illustrating the shapes and colours of the tongue and the arrangements for cleaning the teeth.

March 30.-Dr. A. Smith Woodward, vice-president, in the chair.-Dr. C. F. Sonnta 8: Abnormalities of the abdominal arteries of a young panda.-A. Loveridge: East African lizards collected in $19^{1} 5^{-19}$, with description of a new genus and species of skink and a new sub-species of gecko.

Royal Meteorological Society, March 17.-Mr. R. H. Hooker, president, in the chair.-Capt. C. K. M. Douglas : Clouds as seen from an aeroplane. A large number of photographs of clouds taken from an aeroplane were shown, nearly all of which were taken by the lecturer while flying in co-operation with the Meteorological Section, R.E., in France in I9I8-I9. The primary object of the flights was to obtain the temperature in the upper air for the artillery and for forecasting, and advantage was taken of the opportunity to study cloud-structure and its relation to the upper-air temperature and humidity and to the general meteorological conditions. The observations were made at Berck, on the French coast, twenty miles south of Boulogne, which lies close to the most important aerial routes. The photographs showed a large variety of cloud-forms, and also some changes which took place in short periods. A number of the photographs showed thunderclouds. Thunderstorms are caused by powerful ascending currents, and the tops of the clouds grow up to a great height, frequently exceeding 20,000 ft. Often when the weather is overcast and gloomy there is brilliant sunshine within one or two miles of the ground, and the clouds viewed from above present a splendid spectacle.

PARIS.

Academy of Sciences, March 8.- M. Henri Deslandres in the chair.-G. Humbert: An extension of the modular group in an imaginary quadratic body.F. E. Fournier : Forms of hull of least resistance to their translation in free air at all velocities.C. Guichard: A characteristic property of congruences belonging to a linear complex.-P. Vuillemin : Remarks on a fungus attributed by $M$. Loubière to the genus Trichosporium.-Sir James Dewar was elected a correspondant for the section of general physics in succession to the late Prof. Blaserna.-J. Villey: The adaptation of internal-combustion motors to high altitudes.-B. Gambier : Surfaces of translation applicable to each other.-M. Fréchet : A complete family derived from the family of ensembles "bien definis."P. Humbert : Functions of the parabolic hypercylinder. -M. Renaux : A problem of iteration.-J. K. de Feriet: An application of generalised differentials to the formation and integration of certain linear differential equations.-L. de Peslouian : The extension of the rule of L'Hôpital to certain arithmetical quantities.-J. Chazy: The impossible singularities of the problem of $n$ bodies.-H. Blondel : Application of the method of Lagrange to the orbit of the planet discnvered by $M$. Comas Solà, January $\mathrm{I}_{3}$, I920.-E. Belot: A new form of the law of distances of planets and satellites resulting from the spiral formation of NO. 2633 , VOL. IO5] the planetary system, and the cause of rotation of the planets.-J. Guillaume: Observations of the sun made at the Observatory of Lyons during the third quarter of I9I9. Observations taken on eighty-nine days are summarised in three tables showing the number of spots, their distribution in latitude, and the distribution of the faculæ in latitude.-L. de Broglie : The calculation of the limiting frequencies of $\mathrm{K}$ and $\mathrm{L}$ absorption of the heavy elements. A comparison of the numbers deduced from Bohr's theory and from Végard's formula with the average experimental data derived from the experiments of Végard, Siegbahn, and de Broglie. The results for the $\mathrm{L}$ bands for tungsten, platinum, gold, lead, bismuth, thorium, and uranium are clearly in favour of Végard's formula.-M. Rennesson: The loss of energy in the dielectric of commercial cables. Two sets of experiments are described: in the first the frequency and temperature were maintained constant, and the voltage varied; and in the second the temperature was the variable, voltage and frequency being constant. In the latter case the energy losses in the dielectric showed a minimum at $30^{\circ}$ C.; the losses at $30^{\circ} \mathrm{C}$. were about half those found at $12^{\circ} \mathrm{C}$. or at $55^{\circ} \mathrm{C} .-\mathrm{A}$. Caillas : The search for invertin in pure honey. The presence of invertin in pure honey was definitely proved, and this explains why two analyses of a sample of honey made at different times may give different results for the sugars present. - J. Martinet and O. Dornier: The azo-compounds of indoxyl. - Ch. Boulin and L. J. Simon: The preparation of methyl chloride and bromide starting from dimethyl sulphate. The interaction of concentrated hydrochloric acid and methyl sulphate gives pure methyl chloride; methyl bromide is obtained in a similar manner by substituting a solution of an alkaline bromide acidified with dilute sulphuric acid for the hydrochloric acid.-M. Zeil : The ascensional movements of the earth's crust and the anomalies of gravity.-G. Denizot: The lower peneplain of the Paris basin.-R. Abrard: A layer of eruptive rocks at Souk el Arbâa du R'Arb (Western Morocco).V. Bjerknes: The relation between the movements and temperatures of the upper layers of the atmosphere.-L. Besson: The primitive form of atmospheric ice.-C. E. Brazier: The variation of the indications of the Robinson and Richard anemometers as a function of the inclination of the wind:-A. Guilliermond: The figured elements of the cytoplasm.-J. D. d'Oliveira: The transmission of fasciation and dichotomy as a result of the grafting of two Portuguese vines.-J. Magrou: The immunity of annual plants towards symbiotic fungi.-J. E. Abelous and L. C. Soula: The cholesterinogenic function of the spleen.-J. L. Dantan: Oyster beds: their development, classification, and exploitation.

March 15.-M. Henri Deslandres in the chair.-G. Humbert: The groups of M. Bianchi.-Em. Bourquelot and $M$. Bridel : The detection and characterisation of glucose in plants by a new biochemical method. The production of methyl glucoside by the action of emulsin forms the basis of the new method proposed. -.MM. d'Arsonval, Bordas, and Touplain : The electrical purification of air.-G. Gouv : Gaseous currents in the interior of the sun.-Ch. Nicolle. A. Cuenod, and G. Blanc: The experimental reproduction of trachoma (granular conjunctivitis) in the rabbit.-M. Léon Lindet was elected a member of the section of rural economy in succession to the late Th. Schlœsing, and Sir Joseph Larmor a correspondant for the section of geometrv in succession to the late $M$. Liapounoff.-B. Gambier: Applicable surfaces.Ch. Rabut: The group of plane transformations in which all right lines remain right.-A. Châtelet : 
Abelian bodies of the first degree.-H. Villat: The variable movement of an indefinite fluid with streamlines in presence of a solid body.-R. Thiry: A problem of hydrodynamics admitting an infinity of solutions.-E. Belot : Dichotomic classification of all stars with the hypothesis of their formation by cosmic shock.--Ad. Braly : A new, simple, and rapid method for collecting and characterising the sublimates produced by metalloids and metals volatilised by the blowpipe. Two flames are used, alcohol and paraffin, to secure different temperatures of volatilisation, and the sublimates are received on clear mica sheets.O. Mengel : Two ancient lines of beach at Roussillon : their relations with two Glacial periods.-H. Hubert : Granitic rocks associated with the diabases of the Doualé massif (Haut-Sénégal and Niger).-J. Rouch : The height of sea-waves. The Richard statoscope was used in these measurements; I $\mathrm{mm}$. on the scale of the instrument corresponded to about 0.5 metre variation in height. The greatest wave-heights were observed on January 28 , I910, and gave numerous waves between 4 and 5 metres, fortv above 6 metres, twenty above 7 metres, nine above 8 metres, five above 9 metres, and one of 10.5 metres. Waves of a greater height than Io metres are rare in the Atlantic and the southern seas.-P. Bugnon: The origin of the transverse liberoligneous bundles forming a network at the nodes of the Gramineæ.F. Morvillez: The liberoligneous apparatus of the leaves of Betulaceæ, Corylaceæ, and Castaneaceæ.-L. Blaringhem : The production by traumatism of a new form of maize, Zea Mays, var. polysperma.-J. Barlot : The determination of poisonous varieties of Amanita hy colour reactions. The colour reactions of numerous fungi with sulphuric acid and potash solution are detailed. Three very poisonous varieties give a positive "hæmo-reaction" with a mixture of fresh blood and potassium ferricyanide.- R. Cambier: The purification of sewage by activated sludge.

\section{Books Received.}

A Text-book of Inorganic Chemistry. Vol. ix. Part i. By Dr. T. Newton Friend. Pp. xvii +367. (London: C. Griffin and Co., Ltd.) iss.

Grundzüge der systematischen Petrographie auf genetischer Grundlage. By Dr. W. Hommel. Erster Band: Das System. Pp. xii $+174+5$ Tafel. (Berlin : Gebrüder Borntraeger.) 22 marks.

Mrs. Warren's Daughter. By Sir Harry Johnston. Pp. xi+402. (London: Chatto and Windus.) iss. $6 d$. net.

Recent Developments in European Thought. Edited by F. S. Marvin. Pp. 306. (Ĺondon: Oxford University Press.) r2s. 6d. net.

A Junior Course of Practical Zoology. By the late Prof. A. M. Marshall and Dr. C. H. Hurst. Ninth edition. Revised by Prof. F. W. Gamble. Pp. xxxvi+517. (London: J. Murrav.) r2s. net.

Lectures on the Theory of Plane Curves. By S. Ganguli. Part i. Pp. $x+138$. Part ii. Pp. xiii I30-350+diagrams. (Calcutta: University of Calcutta.)

Applied Aerodvnamics. By G. P. Thomson. Pp. $\mathrm{xx}+292$. (London: Hodder and Stoughton, Ltd.) 42.s. net.

On the Interpretation of Phenomena of Phyllotaxis. (Botanical Memoirs. No. 6.) Bv A. H. Church. Pp. $5^{8}$. (Lnndon: Oxford University Press.) $3 s .6 d$. net.

Half-past Twelve: Dinner Hour Studies for the Odd Half-Hours. By G. W. Gough. Pp. vi+77. (London: Sells. Ltd.) Is.

Utilisation des Algues Marines. By Prof. C. NO. 263.3 , vOL. IO57
Sauvageau. Pp. vi+394. (Paris: O. Doin.) 3.50 francs.

Results of Meridian Observations of Stars made at the Royal Observatory, Cape of Good Hope, in the Years I909-I9Ix. Ppp. $x x+206$. (London: H.M.S.O.) 20s. net.

Fundamental Catalogue of I293 Stars for the Equinox ryoo from Observations made at the Royal Observatory, Cape of Good Hope, during the Years 1905-19II. Pp. xlvi +27 . (Edinburgh: H.M.S.O.) $5^{s}$. Cape Astrographic Zones. Vol. iii. Catalogue of Rectangular Co-ordinates and Diameters of StarImages derived from Photographs taken at the Royal Observatory, Cape of Good Hope. Zone $43^{\circ}$. Pp. xxxvii +443 (Edinburgh: H.M.S.O.) I $5 s$.

Annals of the Cape Observatory. Vol. viii. Part iv. Results of Meridian Observations of the Sun, Mercury, and Venus made at the Royal Observatory, Cape of Good Hope, in the Years 1907 to I9I4. Pp. 93. (Edinburgh: H.M.S.O.) $3 s$.

The Use of Low-Grade and Waste Fuels for Power Generation. By J. B. C. Kershaw. Pp. $\mathrm{x}+202$. (London: Constable and Co., Ltd.) i7s. net.

Colloids in Biology and Medicine. By Prof. $H$. Bechhold. Translated, with Notes and Emendations, by Prof. J. G. M. Bullowa. Pp. xiv +464 . (London : Constable and Co., Ltd.) 3 Is. $6 d$. net.

Bygone Beliefs: Being a Series of Excursions in the Byways of Thought. By H. S. Redgrove. Pp. $\mathrm{xvi}+2 \mathrm{O}_{5}+32$ plates. (London: W. Rider and Son, Ltd.) ros. $6 \dot{d}$. net.

Macmillan's Graphic Geographies: The British Empire. By B. C. Wallis. Pp. 32. (London: Macmillan and Co., Ltd.) rs. $6 d$.

The Nursery-Manual: A Complete Guide to the Multiplication of Plants. By L. H. Bailey. Pp. xi+ $45^{6}+\mathrm{xii}$ plates. (New York: The Macmillan Co.; London: Macmillan and Co., Ltd.) I3s. net.

A Theory of the Mechanism of Survival: The Fourth Dimension and its Applications. By W. W. Smith. Pp. r96. (London: Kegan Paul and Co., Ltd.) $5 \mathrm{~s}$, net.

Roses: Their History, Development, and Cultivation. By Rev. T. H. Pemberton. Second edition. Pp. xxiv +334 . (London: Longmans and Co.) ${ }_{5} 5$. net.

A Short Course in College Mathematics. By Prof. R. E. Moritz. Pp. ix +226 . (New York: The Macmillan Co.; London: Macmillan and Co., Ltd.) Ios. $6 d$. net.

\section{Diary of Societies.}

THURSDAY, APRII. 15.

Rotat. Instifution of Great Britain, at 3.-S. Skinner: Ebullition and Evaporation.

Roval Society of ARTS (Indian Section), at 4.30.-Sir George C. Bucbanan: The Ports of India: Their Administration and Development. LinNean Society, at 5.-Capt. F. Kingdon Ward: Natural History Exploration on the North-east Frontier of Burma.-R. Paulson: Exhibition of Lantern-slides illustrating Definite Stages in the Sporulation and Gonidia within the Thallus of the Lichen Evernia prunastri, Ach. RoYal SocifTy OF MEdicine (Dermatology Section), at 5.

Institution of Mining and Metallurgy (Annual General Meeting) (at Geological Society), at $5 \cdot 3^{\circ} .-$ F. Merricks: The Mineral Production of the Empire (Presidential Address)

Child-Study Societr (at Royal Sanitary Institute), at 6.-Prof. W. Ripman: Spelling Reform.

InSTITUTION OF EleC'TRICAl. ENGINerRS (at Institution of Civil F,ngineers), at 6.-Dr. C. V. Drysdale: Modern Marine Problems (Kelvin Lecture).

OPTICAL SOCIETV (at Imperial College of Science and Technology), at 7.30-J. Weir French: The Unaided Eye, Part III.-R. R at 7.30.- - Weir French: The

Chement ReCall: The Viscosity o HEMICAI. Sociftr, at $8,-1$. Masson and R. McCall: The Viscosity o Nitrocellulose in Mixtures of Acetone and Sturfies in Emulsion. Part I. A New Method for Determining Inversion. -W. H. Gibson and R. McCall: (1) The Influence of Nitroglycerine on the Viscosity of Solutions of Nitrocellulose in Ether-alcohol. (2) The $V$ iscosity of Solutions of Nitrocellulose in Ether-alcohol.-W. K. Slater Experiments on the Preparation of Isonitroso-derivatives.-C. S. Salmon Sodium Ions in Soap Solutions and Gels.-W. C. McC. Lewis : Studies 